\title{
Institutional Capacity Building Of Disaster-Resilient Village in Garut Regency
}

\author{
Rd. Ahmad Buchari ${ }^{1}$, Ivan Darmawan ${ }^{2}$, Kurnia Muhamad Ramdhan ${ }^{3}$ \\ ${ }^{1}$ Department of Public Administration, Faculty of Social and Political Science, Universitas Padjadjaran, Bandung, \\ Indonesia (email: ahmad_buchari@yahoo.com ; ahmad.buchari@unpad.ac.id) ; ${ }^{2 i v a n . i d e v i c e @ g m a i l . c o m ~ ; ~}$ \\ ${ }^{3}$ kurniamr@yahoo.com
}

\begin{abstract}
Disaster may occur anytime and anywhere, and is generally unpredictable. Therefore, the most important to do is disaster management to minimize any harmful impacts of disaster. To be more effective and efficient, it needs to involve all related parties. In regions, the relationship between village institutions is of high importance in disaster mitigation. This is because it is village administration (government) that is in direct relationship with community, and that the latter is one directly impacted by disasters in regions. Thus, in the context of disaster mitigation, the relationship between village institutions should be strengthened. Accordingly, the problem studied in the present research was, how is the strengthening of institutional relationships of villages in Garut Regency? The research method used was a qualitative method. The data collection techniques used were interview and observation. Interview was conducted with village officials and Destana volunteers. And observation was performed in the field on the activities conducted relating to disaster mitigation measures in the four villages which were the research objects, namely, Pasawahan, Rancabango, Mekarjaya, and Karyamekar. The research result revealed that the institutions in the four villages have been good enough but still need to be strengthened in the context of disaster management. The four villages were vulnerable to disasters and have had Destana instrument as a guard of disaster management at village level. In view of the research result, it is suggested that village officials improve their disaster management by, among others, conducting socialization on disaster risks, ways of lessening disaster occurrences, and ways of minimizing losses in case a disaster really occurs.
\end{abstract}

\section{Keywords:}

institusional capacity building; disaster resilient; destana instrument; villages in garut regency

\section{Introduction}

Reformation has come to be the strongest demand in Indonesia. However, in the course of the reformation, a demand for regional autonomy is also steadily intensifying. Regions are pressing for their own sectoral aspirations of building their region without elucidating 
what basic needs of their region are really. The existence of Law No. 23 of 2014 on Regional Governance, Law No. 6 of 2014 on Village, and Law No. 24 of 2007 on Disaster Mitigation even actually causes people confused, being failing to grasp the aspirations of people, particularly that of villagers. Lots of problems then emerge, from conflicts between regions, between regional governments, between regional government and provincial government, to ones between regional government and central government. These conflicts also relate to village institutions, which are the spearhead of development. Different interests try to influence the village institutions.

Therefore, to minimize the conflicts in regions, particularly in villages, there should be villages' good human resource planning and institution strengthening which involves the whole layers of society, especially in disaster mitigation.

Disaster mitigation is provided for in Law No. 24 of 2007 on Disaster Mitigation and in some implementing regulations, e.g., Presidential Regulation No. 8 of 2008 on National Disaster Mitigation Agency, Government Regulation (PP) No. 21 of 2008 on Implementation of Disaster Mitigation, Regulation of Minister of Domestic Affairs No. 46 of 2008 on Organizational Guidance and Procedure of Regional Disaster Mitigation Agency, Regulation of the Head of National Disaster Mitigation Agency No. 3 of 2008 on Guidance of the Establishment of Regional Disaster Mitigation Agency, and Regulation of the Head of National Disaster Mitigation Agency No.11 of 2008 on Guidance of Post-Disaster Rehabilitation and Reconstruction.

The principal institution responsible for disaster mitigation is National Disaster Mitigation Agency (BNPB), a non-ministerial governmental agency headed by a ministerlevel officer. The agency has a duty of formulating and setting disaster mitigation policies and handling refugees promptly, effectively, and efficiently, and coordinating the implementation of the activities of disaster mitigation in planned, integrated, and comprehensive ways. At regional level, a specialized agency that deals with disaster mitigation is Regional Disaster Mitigation Agency (BPBD). It is constituted at both provincial and regency/municipality levels. Like central-level BNPB, BPBDs in regions have 
a duty of formulating and setting disaster mitigation policies and handling refugees and coordinating the implementation of the activities of disaster mitigation.

One of the earlier researches on disaster mitigation was conducted by Ramadhan (2012). He carried out the research in coordination externally, in accordance with the function of each party relating to disaster management. The coordination of Regency-level BPBD with regional government in mitigating natural disasters in Tasikmalaya Regency in form of an interdisciplinary was a coordination in a bid to synchronize actions in order to create discipline among units that shared the same goal, both internally and externally. Meanwhile, interrelated coordination developed was coordination between agencies and institutions whose functions were interdependent or have internal and external links.

Other research was conducted by Fanni Harliani (2014) on the perception of the people of Kampung Cieunteung, Bandung Regency, on Planned Relocation due to Flood Disaster. The research result revealed that a majority of Kampung Cieunteung resisted the planned relocation that the government would execute as an effort to overcome flood disaster. The perception on the planned relocation was connected to some determinants, among them: physical and environmental aspects, economic aspect, community internal characteristics, socio-cultural aspect, information dissemination process, inter-stakeholder communication, and community involvement in decision making processes.

Strengthening institutions existing in villages is a priority in village development program. The role and function of each institution officials come to be a spotlight in relation to administration and finance. This is due to the lack of knowledge (human resource) in the management of an organization (village institution). Village institutions are a very supporting element of village administration (government) in planning and implementing development in the village.

In order to sustain the efforts of building the capacity of village institution as laid down in a village's medium development plan, the institutions should be strengthened. Village institutions serve as a link or bridge of information between the government and people, as well as a carrier of people aspirations in village development. Given the lack of knowledge 
on organizational management in each village institutions, enhancing institutional capacity will be one of the answers for better understanding institutional organization and roles and functions in an institution. Better knowledge will make it easier for village institutions to develop cooperation among them. Moreover, learning an institution's management will positively impact the advancement of the villages in terms of human quality and economy.

Therefore, enhancing villages' institutional capacity, particularly in the handling of disasters, needs a multidisciplinary approach. Otherwise, confidence crisis would emerge. A public confidence crisis is a phenomenon that strongly perils the development of governance condition both in developed and developing countries. It has diverse impacts, and even, at the most extreme point, it may endanger the stability of governance system. Failure of the government to overcome disaster mitigation crisis causes more and more people lose confidence in the government's capability of meeting public needs and protecting public interests from uncertainties and even threats. The failure was resulted from the decreasing performance of the government in responding public interests (Dwiyanto, 2011:393).

The principles of the guidance on disaster risk reduction according to the 2015-2030 Sendai framework emphasize cross-sector participation and cooperation and government, be it central and regional. In addition, community's active participation also receives attention in disaster management today.

As shown on Table 1.1, one of the regions categorized as a disaster vulnerable area in West Java Province is Garut Regency, consisting of 18 Regencies and 9 municipalities. And, according to the 2011 Regency/Municipality Disaster-Vulnerable Index data, Garut Regency even stood at the top of national scale with a category of the highest vulnerable class by a score of 139 (IRBI, BNPB, 2011). 
Picture 1.

Cases of disasters in Garut Regency Year 2011-2015

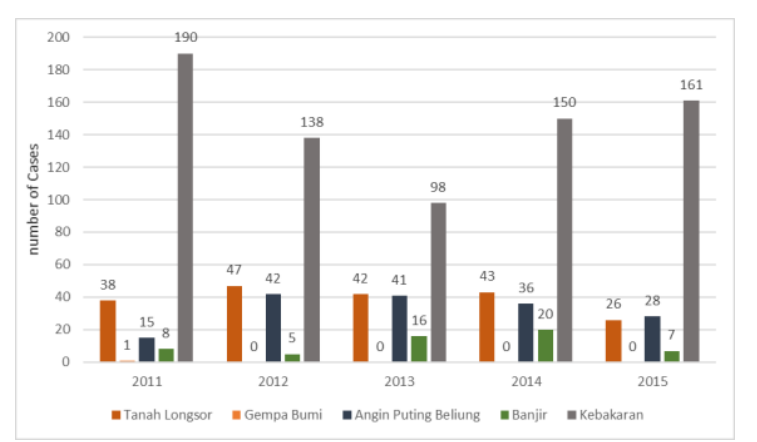

Source: Source: Social, Workforce, and Transmigration Agency of Garut Regency, 2016

Moreover, based on the data of BNPB (2016), the losses from natural disasters that hit Garut Regency in 2017 are shown on the table below.

Table 1.

This caption has one line so it is centered

\begin{tabular}{|c|c|c|c|c|}
\hline \multirow{4}{*}{$\begin{array}{l}\text { Casualti } \\
\text { es }\end{array}$} & \multicolumn{2}{|l|}{ Dead } & \multirow{4}{*}{ Person } & 34 \\
\hline & \multicolumn{2}{|l|}{ Lost } & & 19 \\
\hline & \multicolumn{2}{|l|}{ Wounded } & & 35 \\
\hline & \multicolumn{2}{|l|}{ Evacuated } & & 6,361 \\
\hline \multirow{6}{*}{$\begin{array}{l}\text { Damage } \\
\mathrm{s}\end{array}$} & \multirow{3}{*}{ House } & Major damage & \multirow{6}{*}{ Unit } & 575 \\
\hline & & $\begin{array}{l}\text { Medium } \\
\text { damage }\end{array}$ & & 239 \\
\hline & & Minor damage & & 970 \\
\hline & $\begin{array}{l}\text { Educatio } \\
\text { nal } \\
\text { facility }\end{array}$ & & & 49 \\
\hline & $\begin{array}{l}\text { Religious } \\
\text { facility }\end{array}$ & & & 15 \\
\hline & $\begin{array}{l}\text { Health } \\
\text { facility }\end{array}$ & & & 2 \\
\hline
\end{tabular}

Source: BNPB (2016)

In view of the disaster vulnerable condition of Garut Regency area as seen in the data contained on Chart 1.1 above, BNPB sets a strategy by developing Villages/Kelurahans which are resilient in facing disasters by reducing community-based disaster risk (PRBBK). 
It is hoped that, by the program, each selected village/kelurahan would possess adaptive capacity and preparedness to cope with disaster threats and to recover from disaster impacts. In order to realize Disaster Resilient Village/Kelurahan (Destana), all stakeholders, be they community and Village/Kelurahan officers, have to participate actively and should receive infrastructure, economic, politic, and socio-cultural supports. In addition, the community would have a Community-Based Early Warning System, Contingency Plan, and evacuation path based on their knowledge on their environment. In addition, there should be an economic endurance pattern as a supporting element of survival when a disaster really occurs anytime.

Referring to the statement of the Unit Head of Garut Regency BPBD Prevention (1915), there were some components involved in a realizing disaster mitigation system in villages/kelurahans, namely, regulations concerning disaster prevention and mitigation at kelurahan/village level (legislation), community participation in preparing an action plan on disaster prevention and mitigation (participatory planning), direction from kelurahan/village administration on forming legally/officially disaster-responsive/ready group or community (institution), involvement of community participation by kelurahan/village in preparing Village Development Planning Budget (APBDes/ADD), community self-supporting fund, etc. (participatory budgeting). Last is the empowerment and development of community capacity by holding training, education, and socialization on how to cope with disaster threats, and by performing disaster mitigation from predisaster, disaster, to post-disaster stages.

Given that Garut Regency is a disaster vulnerable area, the government, private sector, and community should be capable of developing cooperation to minimize the number of casualties when a disaster repeat. One of the strategies to pursue for community to be more resilient in coping with natural disasters is by developing disaster-resilient villages/kelurahans. 
Based on the phenomenon described in the research background above, the present study would be an investigation into strengthening village institution in coping with disasters in Garut Regency.

The major problem as the research basis was: Strengthening of institutional relationships of villages in Garut Regency was not going on well. From the major problem, a research question was formulated as follows: How is How is Institutional Capacity Building Of Disater-Resilient Village In Garut Regency?

\section{Method}

Disaster Resilient Village/Kelurahan program is one of the forms of government responsibility for providing people with protection from disaster threats. The goal of developing Disaster Resilient Village/Kelurahan is to protect those people who are living in risky area from the harmful impact of disaster, to increase community role in managing resources in a bid to reduce disaster risks, to enhance societal institution capacity in managing resources and keeping local wisdom for diminishing disaster risks, to increase the capacity of government in supplying resources and technical aids for reducing disaster risks, and to improve cooperation between the stakeholders in PRB, regional government, private sector, higher education, NGOs, societal organizations, and other concerned groups.

Based on the research purpose, the present research was expected to be valuable in describing the responses of regional government, one of which being the responses of village government (administration) in coping with disasters.

The research method used in the present research was qualitative. It was based on the formulation of problem, which required the researcher to perform some explorative activities in attempt to understand and explain the problems the research focused on. Data, data collection technique, and data source used in the research were as follows:

The research result data was obtained directly in the field, by: 
a. Interview, i.e., unstructured interview and semi-structured interview. The former was spontaneously conducted in certain occasions. And in the latter the researcher has set a guide of interview; and

b. Observation, where the researcher took field notes on individuals' behaviors and activities at the research location. In the present research, the researcher conducted an observation as a non-participant.

The informants selected in a qualitative research are ones who have sufficient information on the phenomenon to investigate, and have capacity and competency relating to their major duty and function. An informant-selecting technique begins with performing observation and communication to know who meet the criterion to be an informant.

To determine the reliability of a research, Yin (in Creswell, 2009:190) points out that qualitative researchers need to document the procedures of their studies and to document as many of the steps of the procedures as possible. Therefore, reliability is conducted by documenting the whole stages in the research. The researcher took steps of validating data by a triangulation. Data was valid if it were accurate according to the researcher, participants, and other relevant parties.

According to Creswell (2009), the data analysis stages that a researcher has to take are as follows:

1. Prepares data to be analyzed, in form of the transcript of interview result, scans the document, and re-types notes;

2. Reads all data;

3. Performs coding;

4. Based on the coding result, produces themes as a major finding;

5. Writes a narrative describing the themes and includes them into certain categories; and

6. Interprets or makes meaning of the data. The interpretation can also be derived from a comparison between the findings and information obtained from any literature or theory. 


\section{Result and Discussion}

Disaster Resilient Village/Kelurahan is a national program held under the Regulation of the Head BNPB No. 01 of 2012 on Disaster Resilient Village/Kelurahan Guidance. The program is, in addition to realizing Indonesia Resilient, also a form of government responsibility for its citizens, in this case on disaster mitigation. People are ones that directly suffer the impacts of disaster, as well as ones who firstly respond to any disasters in their surroundings. Thus, they should be provided with capacity for them to be strong in coping with disasters. Some components of the disaster mitigation system in village/kelurahan are then realized in forms of legislation, planning, institution, finance, and capacity building.

Disaster Resilient Village/Kelurahan is one with self-capacity to adapt and cope with potential disasters, and to recover immediately from the negative impacts of the disaster, in case it is really hit by a disaster. Thus, a Disaster Resilient Village/Kelurahan is a village or kelurahan with capacity to recognize threats in its area and capable of organizing community resource for reducing its vulnerability as well as enhancing its capacity for reducing disaster potentials. These capacities are embodied in planning development that includes the measures of prevention, preparedness, disaster risk reduction, and building of the capacity of recovery after an emergency.

The development of Disaster Resilient Village/Kelurahan is one of the communitybased measures of lessening disaster risks. The community-based disaster risk reduction is any measures of reducing disaster threats and people vulnerability, and of enhancing preparedness capacity, planned and implemented by people as the key actor. In a Disaster Resilient Village/Kelurahan, people are actively involved in studying, analyzing, handling, monitoring, evaluating, and reducing disaster risks in their area, especially by utilizing local resources in order to secure sustainability.

The special objectives of the Disaster Resilient Village/Kelurahan are as follows:

1) To protect those communities who reside in risky areas from any harmful impacts of disaster. 
2) To increase community participation, particularly vulnerable groups, in managing their resources in a bid to lessen disaster risks;

3) To enhance the capacity of societal institutions in managing resources and keeping local wisdom for reducing disaster risks;

4) To build the capacity of government in providing resource and technical supports for disaster risk reduction;

5) To promote cooperation between stakeholders in PRB, regional government, private sector, higher education, NGOs, societal organizations, and other concerned groups.

According to Law No. 24 of 2007 on Disaster Mitigation, the government and regional governments are responsible for implementing disaster mitigation. The development of Disaster Resilient Village/Kelurahan is basically part of the realization of the responsibility the regulation of which is delegated to village/kelurahan, and become the responsibility of Village or Kelurahan Administration (Government). Both government and regional government would facilitate the program by supplying resources and technical aids that village/kelurahan needs.

Broadly, Disaster Resilient Village/Kelurahan has the following components:

1) Legislation. Preparation of Village Regulation that regulates both risk reduction and disaster mitigation at village level.

2) Planning. Preparation of Village Disaster Mitigation plan; Contingency Plan when facing certain threats; and Action Plan of Community Disaster Risk Reduction (reduction of disaster risks comes to be an integral part of development);

3) Institution. Establishment of a Village/Kelurahan Disaster Mitigation forum composed of government and community elements, disaster mitigation volunteer group/team in dusun (countryside), RWs and RTs, and development of cooperation inter-sector and stakeholders in encouraging efforts of reducing disaster risks.

4) Finance. Fund and resource mobilization plan (from Regency/Municipality budgets, Village budget/ADD, community self-finance and private sector or other parties if needed); 
5) Capacity building. Training, education, and information spreading to community, particularly volunteer group and disaster mitigation actors for them to have capacity and to play actively as key actors in planning, implementing, and evaluating disaster risk reduction activities; and

6) Implementation of Disaster Mitigation. Activities of structural physical and non-physical mitigation activities; early warning system; vigilance for emergency-responsiveness, and any measures of reducing risks by developmental intervention and recovery program, be it structural-physical and non-structural.

The prospect of Disaster Resilient Village/Kelurahan (Destana) program is very good. Garut Regency, by the role of BPBD, sets a target that in 2019 there will be 15 disaster resilient villages/kelurahans established. One of the indicators of the disaster resilient village/kelurahan is that it has a map of disaster threats, a map and analysis of community vulnerability on disaster impacts, and a map and analysis of resource capacity. Other indicators are availability of a draft Village-Level Disaster Mitigation Plan, a draft Community Action Plan for five years to come, and Disaster Mitigation Volunteers or Forum. In addition, community will be equipped with a Community-Based Early Warning System, a Contingency Plan, and evacuation path(s) based on their own knowledge and capacity, themselves being more familiar with their environment, as well as economic endurance system as a supporting element in keep surviving in case a disaster hits.

Presented here are the results of research conducted in four Disaster Resilient Villages/Kelurahans (Destana) in Garut Regency, namely: Pasawahan, Rancabango, Mekarjaya, and Karyamekar. The research results are divided into five aspects: 1) Legislation; 2) Planning; 3) Finance; 4) Institution; 5) Capacity building; and 6) Implementation of Disaster Mitigation.

1. Legislation

Presentation on the legislation aspect begins with the result of research conducted on the Secretary of Disaster Volunteer Forum (FRB) of Pasawahan Village. The information 
obtained is that the informant was ignorant of the village regulation which regulates risk reduction and disaster mitigation at village level, because he supposed that the authority of enacting village regulation was laid on forum head. The informant simply relied on Law No. 6 of 2014 on Village and Permendagri No. 114 of 2014 on Village Development Guidance as a basis in implementing his duties. Based on the informant's account, it was Forum Head who has authority to enact village regulation, while he was simply the Forum Secretary.

\section{Planning}

The FRB Secretary of Pasawahan Village told, during a session of interview concerning the documents of disaster mitigation plan at the village level, that there was guidance according to the needs of each area, but it was mutually agreed upon that it should comply with a common statute that served as a control in synchronizing visions in the village. Moreover, according to the informant, BPBD did not supply guidance on the plan. Regarding the planning program, the informant told about a contingency plan in coping with village level disaster in form of collecting data of people's valuable goods in order to determine how much the losses are if a disaster hits.

\section{Institution}

In establishing Disaster Mitigation at Pasawahan village-level FRB (Disaster Mitigation Forum), FRB Secretary told that the forum was formed in late 2015 and has been legalized. For its establishment, the forum held training for 30 persons in 2014 to strengthen FRB the function of which is to make preparation in facing disasters in Pasawahan Village, i.e., relating to volcanic eruption, forest fire, flood, landslide, and disease epidemic disasters.

According to an account of a public figure and a Rancabango Village Official, there were many involved in establishing Rancabango Village FRB, among other Regional Disaster Mitigation Agency and Village Head. Then, FRB held training for its membership, around 60 in total, consisting of women, PKKs, RTs/RWs, public figures, etc. 


\section{Capacity Building}

Speaking on capacity building, FRB secretary of Pasawahan Village said that in the forum's capacity building program, the volunteers received training on disaster held by Garut Regency BPBD the materials of which included socialization, disaster identification, contingency, and evacuation paths by disaster maps. In addition, the volunteers were also equipped with a mitigation plan manual. Training was only offered to Destana volunteers. The village officials who received such training were ones who also acted as Destana volunteer. Meanwhile, training has not been offered to general public; they were just supplied with disaster-related information in the events of gathering or pengajian (Islamic sermon).

\section{Implementation of Disaster Mitigation}

\subsection{Reduction of Disaster Risks}

In a bid to reduce disaster risks in Pasawahan Village, an informant, FRB Secretary, said that in this case Pasawahan Village has mapped diverse potential disaster risks as well as evacuation and safe paths according to a study conducted by FRB. The mapping was performed to diminish the risks of various potential disasters. The output of the study and mapping was a disaster potentials map and an evacuation paths map, then socialized to the community and put on village office billboard.

Unlike Pasawahan Village, according to Rancabango Village Secretary and Destana volunteer, maps and study of disaster risks have been available in Rancabango Village. Maps, evacuation paths, and refugee camp have been made available. Marks of evacuation paths in event of a disaster have been fixed. The community was directed to one point of gathering, i.e., at a large square, to make it easier for an evacuating process.

\subsection{Emergency Responsiveness}

In a disaster event, the reductions of disaster risks carried out in Pasawahan Village, according to a volunteer (Mrs. T) were among others by gathering at a safe point, self conditioning, and making sure that families did not suffer stress. Then, when it was safe, the community returned home, and in case there were damages of houses and public 
facilities then they would cooperate to repair them, and to clean debris and dirt. E.g., when there was an overflow on road some time ago, the community participated in cleaning the road for the disaster not to impede social activities and mobility as well as to avoid any accident due to mud on the road.

\section{Conclusions}

Based on the research result, it could be concluded that the institution of villages in Garut Regency, including Rancabango, Pasawahan, Mekarjaya, and Karyamekar, should be strengthened in a context of disaster management. The four villages are areas frequently hit by disasters, and they have had a Destana instrument as a guard of disaster management at village level. This was needed, given that Garut Regency is a disaster prone region. Garut Regency needs to identify the characteristics of its disaster vprone areas, so that it can carry out appropriate preventive measures and even prompt repressive acts in an event of disaster.

\section{References}

Adi, Isbandi Rukminto. 2001, Empowerment, Community Development, and Community Intervention (An Introduction to Practical Thinking and Approach). FE. UI. Jakarta.

Alzwar, Akbar, dan Bachri. 1992. A Geological Map of Garut and Pamengpeuk Sheet, at a 1:100.000 scale. Bandung: Puslitbang Geologi.

Awatona, A. 1997. Reconstruction after Disaster: Issues and Practices. USA: Ashgate Publishing Company.

Blind, Peri K. 2007. Building Trust in Government in the Twenty-First Century: Review of Literature and Emerging Issues. Paper Presenter in $7^{\text {th }}$ GLOBAL Forum on Reinventing Government Building Trust in Government 26-29 June 207. Vienna: Austria.

Carter, Nick. 1991. Disaster Management: A Disaster Manager's Handbook. Manila: Asian Development Bank. 
Creswell, John. W. 2009. Research Design: Qualitative, Quantitative, and Mixed Method Approaches. Sage. California.

Directorate General of Social Aid and Security, Directorate of Social Aids for Natural Disaster Victims. 2003. Technical Guidance of Standardization of Natural Disaster Victims. Republic of Indonesia Department of Social Affairs. Jakarta.

-----------. 2005 Technical Guidance of Standardization of Natural Disaster Victims. Republic of Indonesia Department of Social Affairs. Jakarta.

2005. Guidance of Community-Based Disaster Mitigation. Republic of Indonesia Department of Sosial Affairs. Jakarta.

Howlett, Michael dan Ramesh. 1995. Studying Public Policy: Policy Cycles and Policy Subsystem. Oxford University Press. New York.

Kurniawan, Lilik . 2011. An Indonesian Disaster Prone Index. Jakarta: BNPB.

Miles \& Huberman. 1992. An analysis of Qualitative Data (Textbook on New Methods). UI Press. Jakarta.

Ratman, N. dan Gafoer, S. 1998. A Geological Map of Western Java Sheet at a 1:500.000 Scale. Bandung: Puslitbang Geologi.

Suprapto, dkk. 2011. Indonesian Disaster Atlas 2011. Jakarta: National Disaster Mitigation Agency \& Geospatial Information Agency. 